\title{
Restorationist Counter-Enlightenment: Thomas M'Crie on the Concept of Civil Liberty*
}

\begin{abstract}
Enlightenment notions for Counter-Enlightenment purposes have not to date been used to provide a comprehensive context for Scottish religious history-writing in the age of Counter-Revolution and Restoration. The Evangelical historian and divine Thomas M'Crie's studies on Scottish Reformation history, Life of John Knox and Life of Andrew Melville, published in 1811 and 1819 respectively, exhibit an abundance of historiographical material for research. M'Crie was among the most renowned writers of his own time, but his historical works have been briefly passed over in recent secondary sources. The main purpose of this study is to rescue M'Crie's historical works on the Scottish Reformation past from near oblivion. This article argues that M'Crie produced an apology for the Scottish Reformation, adopting an aggressive style that attacked Scottish Enlightenment historians and thinkers such as William Robertson and David Hume, especially in the matter of their treatment of John Knox and Andrew Melville. M'Crie tried to restore his chosen past in order to influence the religious and political affairs of Scotland. In M'Crie's Counter-Enlightenment historiography, the concept of civil liberty and Presbyterianism become interchangeable in a Restorationist religio-political discourse. That is why M'Crie's enthusiasm for the Scottish Reformation constitutes the most representative example of the Presbyterian interpretation, which held its own against Enlightenment influence.
\end{abstract}

\section{Introduction}

Recent scholarship has touched upon the significant interaction between religious concerns and the newly emerging notions in the Scottish Enlightenment. ${ }^{1}$ However, the scholarly literature on the Enlightenment/Counter-

1. A wide range of Enlightenment ideas not only influenced the attitudes of the Moderates in the Church of Scotland, but also that of the Evangelicals within and outside it. For a detailed discussion of recent literature on the significance of the matters related to religion in the Scottish Enlightenment, see D. G. Tarbuck, "Rethinking the Secularist Enlightenment Project in Scotland," Intellectual History Review 17 (2007): 337-44; also see R. B. Sher, Church and University in the Scottish Enlightenment: The Moderate Literati of Edinburgh (Princeton: Princeton University Press, 1985); J. R. McIntosh, Church and Theology in Enlightenment Scotland, The Popular Party, 1740-1800

Fatih Durgun is a PhD candidate at the Department of History, Bilkent University, Ankara, Turkey. * This article is based on my earlier research on the historical works of Thomas M'Crie, entitled "Enlightenment and Reformation in the Historical Writings of Thomas M'Crie," (Unpublished M.A. thesis, Bilkent University, 2007). For their helpful comments and suggestions, I would like to thank Stewart J. Brown, C. D. A. Leighton, David Thornton, Zeki Sarıgil, Selim Tezcan, Alperen Topal, M. Burak Özdemir, and Fatih Çalışır. 
Enlightenment ${ }^{2}$ debate as well as the employment of Enlightenment notions for Counter-Enlightenment purposes have not been used to provide a comprehensive context for Scottish religious history-writing in the age of CounterRevolution and Restoration. This neglect seems a little odd, considering the fact that a coterie of Scottish religious figures, such as William Robertson and Adam Ferguson, played a leading role in the dissemination of Enlightenment notions, including "stadialism" and "civil liberty," and that Scotland was a part of the North Atlantic Evangelical Revival. ${ }^{3}$ Despite this negligence, it is evident that there was much thought expanded on religio-political conflicts in the works produced in the period extending from the Enlightenment to the separation of the numerous Evangelicals ${ }^{4}$ from the Church of Scotland in the Disruption of 1843. The rise of the Evangelicals especially highlights the consolidation of post-Enlightenment conservatism and reaction to the revolutionary politics of the period. ${ }^{5}$ In this sense, it is necessary for us to reconsider the material from the early nineteenth-century Scottish historiography and see how Enlightenment and Counter-Enlightenment notions were utilised in the religio-political discourse.

(East Linton: Tuckwell Press, 1998); N. C. Landsman, "Presbyterians and Provincial Society: The Evangelical Enlightenment in the West of Scotland, 1740-1775," in Sociability and Society in Eighteenth Century Scotland, edited by J. Dwyer and R. B. Sher (Edinburgh: Mercat Press, 1993), 194-209. C. Kidd, "Subscription, the Scottish Enlightenment and the Moderate Interpretation of History," Journal of Ecclessiastical History 55 (2004): 502-19.

2 . For a recent comprehensive discussion of Counter-Enlightenment, see G. Garrard, CounterEnlightenments: From the Eighteenth Century to the Present (New York: Routledge Press, 2006). For contextualization of Enlightenment and Counter-Enlightenment concepts in different countries, particularly see D. M. McMahon, Enemies of the Enlightenment: The French CounterEnlightenment and the Making of Modernity (Oxford: Oxford University Press, 2001). For the British case, see especially a series of articles published by C. D. A. Leighton such as "Hutchinsonianism: A Counter-Enlightenment Reform Movement," Journal of Religious History 23 (1999): 168-84.

3. These two points have been frequently emphasised in modern historiography. For example, William Robertson and the Expansion of Empire, edited by S. J. Brown (Cambridge: Cambridge University Press, 1997); F. Oz-Salzberger, Translating the Enlightenment: Scottish Civic Discourse in Eighteenth-Century Germany (Oxford: Clarendon Press, 1995); Nation and Province in the First British Empire: Scotland and the Americas 1600-1800 edited by N. C. Landsman (Lewisburg: Bucknell University Press, 2001); J. M. Yeager, Enlightened Evangelicalism: The Life and Thought of John Erskine (Oxford: Oxford University Press, 2011), 141-65; D. W. Howe, "John Witherspoon and the Transatlantic Enlightenment," in The Atlantic Enlightenment, edited by S. Manning and F. D. Cogliano (Aldershot: Ashgate, 2008), 61-80.

4. It is true that Evangelicalism had some basic components throughout the transatlantic world in the late eighteenth and early nineteenth centuries such as an emphasis on conversion experience, Biblicism, vital and personal religion; however, as scholars such as David Bebbington and Mark Noll have pointed out, it is hard to give a coherent definition for Evangelicalism due to different social characteristics and geographical locations. See D. W. Bebbington, The Dominance of Evangelicalism: The Age of Spurgeon and Moody (Downers Grove: Intervarsity Press, 2005), 21-81. M. A. Noll, The Rise of Evangelicalism: The Age of Edwards, Whitefield and the Wesleys (Downers Grove: InterVarsity Press, 2003), 19. So the concept is somewhat complicated. It should be indicated that although Scottish Evangelicalism had also mentioned existing set of characteristics, Evangelical Presbyterianism within and outside the Church was mainly preoccupied with the problem of ecclesiastical jurisdiction as it is evident in the debates between the Popular Party and the Moderates in the Church of Scotland and the New Licht-Old Licht controversy in the Secession Churches. These points have been discussed in the article. Also see D. W. Miller, "Presbyterianism and 'Modernization' in Ulster," in Nationalism and Popular Protest in Ireland, edited by C. H. E. Philpin (Cambridge: Cambridge University Press, 2002), 80-109.

5. D. W. Bebbington, Evangelicalism in Modern Britain: A History from the 1730s to the $1980 \mathrm{~s}$ (London: Routledge, 1989), 48-59. 
The studies of the evangelical historian and divine Thomas M'Crie on Scottish Reformation history, Life of John Knox and Life of Andrew Melville, which were published in 1811 and 1819 respectively, present valuable material that reflects the religio-political conflicts of the early nineteenth century. Indeed, M'Crie (1772-1835) may be little known today, but he was among the most renowned writers of his own time. ${ }^{6}$ Among the literary figures of his age, M'Crie was surpassed in the public estimation only by Sir Walter Scott, as his historical works were very well received and several reviews written about them. ${ }^{7}$ M'Crie's Reformation biographies were first published by William Blackwood, one of the leading publishers of Edinburgh. ${ }^{8}$ Thomas M'Crie's achievement as a historian was not merely restricted to his Scottish Reformation biographies. Additionally, M'Crie authored two works on the suppressed Reformation attempts in sixteenth-century Italy and Spain. ${ }^{9}$

M'Crie was nurtured in a circle of the "Anti-Burgher Seceders," who separated from the Secession Church and formed the General Associate Synod (the "Burgher Seceders," on the other hand, were commonly known as the Associate Synod) in 1747 after their rejection of the Burgess Oath. This oath necessitated the taker to swear allegiance to the civil authorities, ${ }^{10}$ and involved an ambiguous clause requiring profession to "the true religion" as settled in the Established Church. ${ }^{11}$ For the "Anti-Burghers," this meant the abandonment of the founding principles of the Secession Church and was totally unacceptable, since they considered the Established Church to have been degenerated by the restoration of lay patronage in 1712. Within this theologically conservative section of Scottish Presbyterianism, M'Crie was a leader and the most able spokesman of those who resisted "an easing off of the intenseness and of the conviction with

6. There is no biographical study of Thomas M'Crie by a professional historian. The sole work on his life was written by his son Thomas M'Crie the Younger. The author gives the details of his father's life in a very eulogistic way: T. M'Crie the Younger, Life of Thomas M'Crie (Edinburgh, $1840)$.

7. For illustration, see p. 4, and ftn.17, 18 and 19. For M'Crie's historiography in modern scholarship especially see G. H. Forsyth, "The Presbyterian Interpretation of Scottish History, 1800-1914," (unpublished PhD diss., University of Stirling, 2003), 53-98. C. Kidd: Subverting Scotland's Past: Scottish Whig Historians and the Creation of an Anglo-British Identity, 1689c. 1830 (Cambridge: Cambridge University Press, 1993), 201-3.

8. I. Duncan and D. Mack, "Hogg, Galt, Scott and their Milieu," in The Edinburgh History of Scottish Literature, Vol. 2 Enlightenment, Britain and Empire 1707-1918, edited by I. Brown, T. O. Clancy, S. Manning and M. Pittock (Edinburgh: Edinburgh University Press, 2007), 211-20.

9. See T. M'Crie, History of the Progress and Suppression of the Reformation in Italy (Edinburgh, 1827); and T. M'Crie, History of the Progress and Suppression of the Reformation in Spain (Edinburgh, 1829). For instance, see E. G. Gleason, "On the Nature of Sixteenth-Century Italian Evangelism: Scholarship, 1953-1978," Sixteenth Century Journal 9 (1978): 3-26; J. Martin, Venice's Hidden Enemies: Italian Heretics in Renaissance City (Berkeley: University of California Press, 1993), 257. Martin considers M'Crie's book as "the most readable" of many general works on the Italian Reformation which were written in the nineteenth century. M'Crie's Spanish Reformation history has become influential on nineteenth-century American historian William H. Prescott. See E. Peters, Inquisition (Berkeley: University of California Press, 1999), 285. For an illustration of this influence see also F. Braudel, The Mediterranean and the Mediterranean World in the Age of Philip II, trans. by Siann Reynolds (Berkeley: University of California Press, 1995), ii, 767.

10. T. M. Devine, The Scottish Nation 1700-2000 (London: Allen Lane, 1999), 89.

11. J. M'Kerrow, History of the Secession Church (Glasgow, 1841), 212. This is still the best and most detailed account of the controversies and debates among the Seceders. 
which the old truths were held and taught." 12 The result of the resistance was the formation in 1806 of the Constitutional Associate Presbytery, whose members were known as the "Auld Licht Anti-Burghers." The "old truths" were those that justified the theocratic beliefs of the seventeenth-century Covenanters.

M'Crie was apparently revered by the Evangelicals in the Church of Scotland prior to the Ten Years' Conflict (1834-1843) during which "there was an intense and bitter contest" between Moderates and Evangelicals over patronage and evangelisation. ${ }^{13}$ As an "Auld Licht Anti-Burgher," M'Crie was attached to the national Establishment principle, although he came from the Secession tradition which, protesting against lay patronage had separated from the Established Church in $1733 .{ }^{14}$ Similarly, attachment to the Establishment principle and protest against lay patronage were characteristic of the Evangelicals in the Church of Scotland before the Disruption of $1843 .{ }^{15}$ This was one of the main reasons for the Evangelical lauding of $\mathrm{M}^{\prime} \mathrm{Crie}$ in correspondence and the press. In the $1820 \mathrm{~s}, \mathrm{M}^{\prime}$ Crie contributed to the formation of the Anti-Patronage Society along with the leading Evangelicals in the Church of Scotland, such as George Sinclair and Andrew Thomson. ${ }^{16}$ In one of his letters to M'Crie, Sinclair indicated that his erudite work on John Knox would hand down his name to "succeeding generations" of Scotland, "as well as to those of the present day." ${ }^{17}$ For Sinclair, M'Crie was "one of the first of modern historians; one, who triumphantly vindicates the character of" John Knox, not only through erudite research on the sources of his time, "but by exemplifying in his life and doctrine, the salutary influences of those principles, which our reformers taught and practised." 18 M'Crie's scholarly merits were highlighted especially in the Edinburgh Christian Instructor, which served the cause of the Evangelicals under the editorship of Andrew Thomson. ${ }^{19}$

12. J. MacLeod, Scottish Theology in Relation to Church History since the Reformation (Greenville: Reformed Academic Press, 1973), 229.

13. C. G. Brown, Religion and Society in Scotland since 1707 (Edinburgh: Edinburgh University Press, 1997), 21.

14. This view of M'Crie is also observable in a pamphlet which was written by his mentor Archibald Bruce: A. Bruce, The Cathecism Modernized: And Adapted to the Meridian of Patronage and Late Improvements in the Church of Scotland: With Suitable Creeds and Prayers (Edinburgh, 1791), 12. For these points, see Kidd, "Subscription," 502-19, also see n. 48 below. Particularly in the 1830s, the Evangelicals became closer with both "Auld Licht Burghers" and "Auld Licht Anti-Burghers." They praised both "Auld Licht" parties before most of the "Auld Licht Burghers" went to the Established Church in 1839. See Church of Scotland Magazine, February 1838, 65-72.

15. They did not leave aside the Establishment principle even when they separated from the Established Church and formed the Free Church in 1843. Thomas Chalmers would indicate this very clearly in the First General Assembly of the Free Church of Scotland: "We go out on the Establishment principle, ... but would rejoice in returning to a pure one ... - we are the advocates for a national recognition and national support of religion, and we are not Voluntaries." T. Chalmers, The Addresses Delivered At The Commencement And Conclusion of The First General Assembly of The Free Church of Scotland (Edinburgh, 1843), 7.

16. L. Rose, An Humble Attempt to Put an End to the Present Divisons in the Church of Scotland and to Promote Her Usefulness (Glasgow, 1840), 24.

17. M'Crie the Younger, Life, 292. For M'Crie's correspondance with Sinclair and Thomson, see M'Crie the Younger, Life, 291-98, and 212-21.

18. Edinburgh Christian Instructor, January 1825, 47.

19. For example, in 1812, two reviews of M'Crie's Life of John Knox appeared in the Edinburgh Instructor. One of them eulogistically reads as follows: "The result of his examination is, in the 
M'Crie wrote his works in the post-Enlightenment period, but, as a creative recipient and transmitter of Enlightenment notions, he cannot be left out of the history of the Enlightenment debate. Like many of the Scottish Evangelicals of his time, M'Crie drew upon some components of Enlightenment thought. In his historical works M'Crie selectively used the Enlightenment rhetoric of progress, although he kept his distance from some aspects of enlightened evangelicalism such as voluntarism and religious pluralism. ${ }^{20}$ On the other hand, M'Crie's historiography should be considered within the context of an evangelical counter-Enlightenment that would develop amidst other religious debates during the rest of the century. ${ }^{21} \mathrm{He}$ was sharply critical of the enlightened Moderatism in the Church of Scotland, which consisted of a flexible reinterpretation of Calvinist theology, as well as of the voluntarism prevailing in the Secession Churches. However, M'Crie's Counter-Enlightenment position was not exclusively philosophical or religious; rather more, it had a strong historical dimension.

In his Life of John Knox and his Life of Andrew Melville, he produced an apology for the Scottish Reformation, adopting an aggressive style that attacked Scottish Enlightenment historians and thinkers like William Robertson and David Hume, especially for their treatment of John Knox. As he criticised the Enlightenment writers' interpretations of the Scottish Reformation, he also employed such Scottish Enlightenment notions as "stadialism" and "civil liberty." 22 Thus one should take note of his convergence of Enlightenment and Counter-Enlightenment notions. Taking up a defensive position, M'Crie tried to restore his chosen past in order to respond to the religio-political discussions of his time. In M'Crie's Counter-Enlightenment

greatest degree, satisfactory and conclusive." See Edinburgh Christian Instructor, September 1812, 182. See also Edinburgh Christian Instructor August, 1812, 116-17. M'Crie also himself contributed to the Edinburgh Christian Instructor. He published a long review of Walter Scott's Old Mortality and criticised Scott's representation of the Covenanters in the monthly issues of the Edinburgh Christian Instructor between January and March 1817. M'Crie's lengthy review was published in T. M'Crie, A Vindication of the Scottish Covenanters: Consisting of A Review of the First Series of the "Tales of My Landlord" (Philadelphia, 1843), 142.

20. Though he was theologically conservative, M'Crie was, to some extent, politically under the influence of liberal progressive ideas. He was an activist who delivered public speeches on Greek Independence in the 1820 s and actively participated in anti-slavery agitation in 1830 along with popular Evangelical zeal for the abolition of slavery. See M'Crie the Younger, Life, 276-79. It should also be noted that although he was strictly attached to Calvinist/Presbyterian theological orthodoxy, he made a clear distinction between Scottish Presbyterianism and Genevan Calvinism. He would reject the assertions of William Robertson that John Knox and Andrew Melville had merely appropriated the persecutory principles of Calvin. For Robertson's view on Knox and Melville see Kidd, Subverting Scotland, 191. In a correspondence with the Rev. William Tweedie on Calvin, he would indicate his distance from "any principle" which could lead to persecution. M'Crie the Younger, Life, 382. M'Crie acknowledged that it could be said for both Knox and Melville that they had been "greatly indebted to Calvin and Beza." Further, "they admired the religious order and discipline established in Geneva," but it was impossible to assert that they had unquestioningly adopted and copied the institutions in that city. T. M'Crie, Life of Andrew Melville, New Edition (Edinburgh, 1899), 61. What had shaped their teaching was not a simple observation of Genevan ecclesiastical government and discipline, but a comparison of this with what constituted a "divinely authorized" form of ecclesiastical government. T. M'Crie, Life of John Knox, 5th ed. (Edinburgh, 1850), 62.

21. M. Lynch, Scotland: A New History (London: Pimlico, 1992), 356.

22. Kidd, Subverting Scotland, 202. 
historiography, the concept of civil liberty and Presbyterianism became interchangeable in a Restorationist religio-political discourse. ${ }^{23}$ Therefore, the influence of Restorationist discourse on M'Crie's historiography, his stance about the Counter-Enlightenment, and his differences and similarities with Scottish Enlightenment figures are among the issues that require closer attention. In the following, I will show that M'Crie followed the main approach of Enlightenment historiography, such as progressivism and historical teleology, while employing Enlightenment notions in a recognisably different sense than his Enlightenment predecessors: he used these to build a powerful Restorationist Counter-Enlightenment Presbyterian historical discourse.

\section{Restorationist Historical Method of M'Crie}

In order to understand M'Crie's religio-political stance better, first we need to understand how he communicated his Restorationist historical methodology. In the Preface to his Life of John Knox, M'Crie stressed the need to rescue the images of John Knox and Andrew Melville from the pejorative comments of popular Enlightenment thinkers in his age. Quite simply, their depictions were "false" and they "should have been suppressed." The assaults made on the personalities of Knox and Melville were various, full of errors and "uncandid and exaggerated censures." ${ }^{24}$ It was thus a pressing necessity to present the virtuous characters of the Reformers. To fulfill this moral and religious purpose, M'Crie responded to such Enlightenment figures as William Robertson and David Hume by placing some of the documentary "facts in a new and more just light" as well as by collecting others which had been unknown until then. ${ }^{25}$ For M'Crie, "the pages of ecclesiastical history are too often filled with accounts of theological contention," and they represented the characters either as aggressive or stubborn. ${ }^{26}$ For this reason, it was quite difficult "to form a correct and impartial estimate of the talents and character of those who have distinguished themselves in great national struggles." ${ }^{27}$ Documents such as the declarations of statesmen and reports and registers of the parliaments were used as evidence to support his case against the Enlightenment writers. This shows that he drew heavily on the rich Scottish historiographical tradition based upon erudite research of primary sources and archival materials. ${ }^{28}$ In the Scottish Calvinist-Presbyterian tradition, attachment to the documentary and

23. See C. Leighton, "George Chalmers and the Reformation: Writing Scottish History in the Age of Counter-Revolution and Restoration," Archivium Hibernicum 59 (2005): 290-305.

24. M'Crie, Knox, ix.

25. M'Crie, Knox, viii.

26. M'Crie, Melville, 341.

27. M'Crie, Melville, 340.

28. For instance, the Enlightenment writer William Robertson extensively used primary documents in his works. As an example for its discussion, see S. J. Brown, "William Robertson, Early Orientalism, and the Historical Disquisition on India of 1791," Scottish Historical Review 88 (2009): 289-312. This methodological characteristic of Robertson's historiography actually demonstrates us how M'Crie was deeply influenced by Enlightenment historiography in spite of his Counter-Enlightenment position. For Robertson's importance as a historian especially, see K. O'Brien, "Robertson's Place in the Development of Eighteenth-Century Narrative History," in William Robertson and the Expansion of Empire, edited by Brown, 74-91; and other essays published in that volume. 
primary evidence for communicating the religious and political facts became gradually crucial with John Knox and his successors like David Calderwood, James Kirkton and James Wodrow. Calvinists were of the opinion that a "peculiar importance" was attached to the spreading of an accurate historical narrative. ${ }^{29}$ History, as events, served to communicate religious truth, for God remained at the centre of those events, directing and shaping their course. Hence, history as a way of dissemination of revealed truth was to be put into practice by "evidence" and "testimony" rather than by "narrative" and "interpolation." ${ }^{30}$ For M'Crie, "truth, eternal truth" was the "immovable basis of the church." 31 Thus, through such a methodological approach, historical works might function very well to eliminate the "mistakes, whether they have originated in ignorance or in prejudice." 32

In this sense, concern with restoring the truth from the past was the backbone of M'Crie's historiography. M'Crie's historiographical stance can be labelled as part of European-wide Restorationist thought. In general, "Restorationism" was a general socio-political and religious outlook for sustaining a pure Christian "social and political order" against the French revolutionary ideas. The purpose for the Restorationists was to build "a future shaped by a purified adherence" to the principles derived from the past. ${ }^{33}$ At first sight the concept of Restorationism seems to be peculiar to the British context, since it commonly stands for the rise of Ultramontanism on the Continent and the restorationist religio-political views of Joseph de Maistre and Louis de Bonald. For the French Restorationist thinkers, religion was the essential component of the political society. The compatible and harmonious relationship between church and state would secure the proper running of civil society against the danger of secularist ideas, since this was the real basis of Christendom. ${ }^{34}$ Both Maistre and Bonald offered a return to the infallible authority of the Catholic Church as the foundation of truth to guarantee the organic unity of the society. ${ }^{35}$

The use of the concept also seems to have been convenient for the reactionary religious movements in Britain during the first half of the nineteenth century. Like the French Ultramontane reaction to Gallicanism and the French Revolution, the anti-Erastian stance of the Oxford Movement in England and the Evangelical protest within the Church of Scotland before the Disruption of

29. D. Allan, Virtue, Learning and the Scottish Enlightenment: Ideas of Scholarship in Early Modern History (Edinburgh: Edinburgh University Press, 1993), 51.

30. Allan, Virtue, 53.

31. T. M'Crie, "On the Importance of Right Principles in Religion, and the Danger of Those that are False," Christian Magazine, February 1797, 23. Cited from Forsyth, "Presbyterian Interpretation," 53.

32. M'Crie, Melville, 341.

33. Leighton, "George Chalmers and the Reformation," 290-305.

34. M. A. Perkins, Christendom and European Identity: The Legacy of A Grand Narrative Since 1789 (Berlin: Walter de Gruyter, 2004), 22-27.

35. Like de Maistre, de Bonald and M'Crie, Edmund Burke thought religion as the basis of civil society. He would also indicate that "in a Christian Commonwealth the Church and the State are one and the same thing, being different integral parts of the same whole." Speech on the Petition of the Unitarians (11 May 1792). Cited from M. W. McConnell, "Edmund Burke's Tolerant Establishment," in Religious Liberty in Western Thought, edited by N. B. Reynolds and W. C. Durham, Jr (Grand Rapids: Eerdmans, 1996), 203-44, at 204. 
1843 certainly shared some common features despite their differing political ecclesiologies. ${ }^{36}$ These movements rejected an Erastian Church subordinate to the secular state. In addition, they all tended to turn to the past to support their arguments in contemporary debates. For example, in the words of John Henry Newman, one of the leading figures of the Oxford Movement, "Erastianism then was the one heresy which practically cut at the root of all revealed truth." 37 History, "the review of past times," would be one of the ways of "attaining religious truth," 38 with a view to the proper understanding and restoration of the church-state relations as well as to the repulsion of the attacks on Christian religion. Besides, considering the fact that most of the American Evangelicals essentially shared the same religious tenets and had close links with their Scottish counterparts, ${ }^{39}$ it is also possible to read M'Crie's Restorationist attitude within a broader transatlantic context.

The similar discussions and tensions in terms of church-state relations and civil liberty were available in American Presbyterianism. Like the Scottish "New Licht" Seceders, most of the American Presbyterians accepted the issuing of the American version of the Westminster Confession, particularly revising the clauses on the limits of the duty of the civil magistrate under the influence of John Witherspoon in $1789 .{ }^{40}$ In reaction to the limitations upon the object of the civil magistrate, some American Presbyterians like Covenanter minister Samuel B. Wylie would attack the ideas for total separation of church and state. In exactly the same manner as M'Crie's view for church-state relations discussed below, Wylie would write that the ecclesiastical and civil authorities could be in coordination with and mutual dependence on each other. ${ }^{41}$ As another example, a Congregationalist and the president of Yale, Timothy Dwight, in parallel to M'Crie and French Restorationist thinkers, would display an anti-revolutionary conservative attitude to the alarming "irreligious" and "infidel" opinions springing from the French Revolution. Dwight, in his widely known political sermon The Duty of Americans at the Present Crisis, underlined that the dissemination of "infidelity" and "irreligion" by the Illuminati societies would cause "the overthrow of religion, government, and

36. For the similarities between the political ideas of the Oxford Movement and French Restorationist thought of de Maistre and de Boland, see P. Nockles, "Church and King: Tractarian Politics Reappraised," in From Oxford to the People: Reconsidering Newman and the Oxford Movement, edited by P. Vaiss (Leominster: Gracewing, 1996), 93-123. Cited from Leighton, "George Chalmers and the Reformation," 290-305.

37. J. H. Newman, Lectures on Certain Difficulties Felt By Anglicans in Submitting to the Catholic Church (Dublin, 1857), 83.

38. J. H. Newman, Lectures on the Present Position of Catholics in England: Addressed to the Brothers of the Oratory (Dublin, 1857), 53.

39. Yeager, Enlightened Evangelicalism, 142; R. L. Emerson, "The Scottish Literati and America, 1680-1800," in Nation and Province, edited by Landsman, 183-220.

40. J. W. McGinty, “An Animated Son of Liberty”: A Life of John Witherspoon (Bury St. Edmunds: Arena Books, 2012), 63-71.

41. S. Wylie, The Two Sons of Oil; or, the Faithful Witness for Magistracy and Ministry Upon a Scriptual Basis. Third Edition With An Essay on Submission to Civil Government (Philadelphia, 1850). Another American Presbyterian William Findlay would reply to the religio-political opinions of Wylie in his Observations on "The Two Sons of the Oil": Containing a Vindication of the American Constitutions, and Defending the Blessings of Religious Liberty and Toleration, against the Illiberal Strictures of the Rev. Samuel B. Wylie, edited by J. Caldwell (Indianapolis: Liberty Fund, 2007). 
human society, civil and domestic." Furthermore, he apprehensively indicated that "if our religion were gone, our state of society would perish with it; and nothing would be left which would be worth defending." 42

These examples from different religio-political positions and different countries in the age of Counter-Revolution might explain why M'Crie's antiErastian and essentialist Presbyterianism should be considered within a general Restorationist religio-political discourse. In summary, the nature of revolutionary and post-revolutionary politics shaped Restorationist thought as a reaction to the possible dangers of a resurrection of the ideas of the French Revolution. In terms of religious restoration, it was particularly a reaction to the continuing Enlightenment interpretation of religion and its relative position in state affairs. ${ }^{43}$ In Protestant countries, as a natural consequence of the religious revival movements among the Anglicans, Lutherans, and Calvinists, the confessional Protestants looked back to their founding eras "in search of guidance for defining Protestant community and piety." In this sense, these Protestant movements stressed the predominance of the authority of statements such as the Augsburg Confession of Faith or the Thirty-Nine Articles. ${ }^{44}$ As common characteristics, all these Restorationist movements countered the scepticism and materialism that were dominant during the later stage of the Enlightenment as well as the rationalism and moderatism that infiltrated the established churches. ${ }^{45}$ In the Scottish case, this idea of religious restoration was manifest essentially in the hostility of the Evangelical movement to the Moderate Party in the Established Church, since the former defended Orthodox Presbyterianism. It should be noted that the roots of this conflict had deep foundations in the first half of the eighteenth century. The conflict between the Moderates and the Evangelicals is commonly traced back to the debate over the Patronage Act of 1712 which gave the right of appointment of ministers to lay patrons. Its acceptance, together with what was perceived as Moderatism among the clergymen, provoked many Presbyterians to secede in protest from the Established Church and to found the Secession Church in $1733 .{ }^{46}$ Later, this multi-faceted controversy that centred on Scotland's church-state relations would cause the Disruption of 1843 and the creation of the Free Kirk.

The theological and political disputes among the Seceders differed to a certain degree from those that divided the Church of Scotland. In the Secession Churches, the debate that led to the divisions focused mainly on the authority

42. The quotations are cited from S. K. Green, The Second Disestablishment: Church and State in Nineteenth-Century America (Oxford: Oxford University Press, 2010), 87-88.

43. For various reactions to the Revolutionary and Enlightenment in national context and ecclesiology of Presbyterian church-state relations see N. Aston, Christianity and Revolutionary Europe, c.1750-1830 (Cambridge: Cambridge University Press, 2002), 134-71.

44. A. J. Steinhoff, "Protestantism," in A Companion to Nineteenth-Century Europe, 1789-1914, edited by S. Berger (Oxford: Blackwell, 2006), 248-61, see also Leighton, "Chalmers and the Reformation," 290-305.

45. S. J. Brown, "Movements of Christian Awakening in Revolutionary Europe, 1790-1815," in The Cambridge History of Christianity: Enlightenment, Reawakening and Revolution, 1660-1815, VII, edited by S. J. Brown and T. Tackett (Cambridge: Cambridge University Press, 2008), 575-95. 46. S. J. Brown, "Religion and Society to c. 1900," in The Oxford Handbook of Modern Scottish History, edited by T. M. Devine and J. Wormald (Oxford: Oxford University Press, 2012), 78-98. 
of the civil magistrate, as can be seen in the controversy between the "New Lichts" and "Auld Lichts" in the late eighteenth and early nineteenth centuries. The controversy revolved around the question whether civil rulers had any right or reason to interfere with religious issues. ${ }^{47}$ It had an intrinsically historical character. It was not merely constituted by contemporary differences of interpretation, occasioned by individualistic or communal perceptions of CalvinistPresbyterianism. In terms of political theology, the controversy was closely linked to the position of the church on the "Confession or the Covenants." While the "Auld Lichts" kept "their commitment to a state Church,"49 the "New Licht" ideas represented a significant shift in the position of Presbyterian Dissenters, one from a sort of restoration of the Covenants to a rejection of any kind of link between the church and the state. ${ }^{50}$ In a broader intellectual and religio-political context, the Enlightenment thought and the political atmosphere of the French revolutionary era shaped the development of this controversy.

On the one hand, the "New Licht" drew heavily upon Scottish Enlightenment's emphasis on individualism and civic thought. ${ }^{51}$ On the other hand, the radical religio-political French revolutionary ideas about the impartiality of the state in religious matters influenced the views about the duty of the civil magistrate and Westminster Standards. ${ }^{52}$ A profound consequence of the "New Licht" controversy was the questioning of the legacy of Scottish Reformation among the Seceders. Under the effect of progressive and rational opinions, the

47. Annals and Statistics Of The Original Secession Church: Till its Disruption and Union With The Free Church of Scotland in 1852, edited by D. Scott (Edinburgh, 1886), 81; M'Kerrow, Secession Church, especially ch. XVII.

48. A. Herron, Kirk by Divine Right: Church and State, Peaceful Coexistence (Edinburgh: Saint Andrew Press, 1985), 79.

49. C. Kidd, "The Kirk, the French Revolution, and the Burden of Scottish Whiggery," in Religious Change in Europe 1650-1914: Essays for John McManners, edited by N. Aston (Oxford: Oxford University Press, 1997), 213-34.

50. S. J. Brown, The National Churches of England, Ireland and Scotland 1801-1846 (Oxford: Oxford University Press, 2001), 44. There was no party in the Church of Scotland comparable to the "New Licht" Seceders in terms of their opinions on voluntarism, disestablishment, and disendowment. The Moderates were attached to the Establishment principle even though their eschewal of the Calvinist theology of the seventeenth century somewhat resembled the "New Licht" theology. As Richard Sher points out, "the Moderates sought to shift the emphasis of Scottish Presbyterianism from predestination and election to individual and social morality." Sher, Church and University, 35. On the other hand, as has been mentioned before, the Evangelicals, like the "Auld Licht" Seceders, were attached to the principles of seventeenth-century Calvinism. Although they were in dispute with the Moderates on issues like patronage, they were attached to the Establishment principle. However, Churchmen from the Free Church put the religious establishment idea aside, and "campaigned for disestablishment in the period 1874-1886." I. Machin, "Disestablishment and Democracy, c. 1840-1930," in Citizenship and Community: Liberals, Radicals and Collective Identities in the British Isles: 1865-1931, edited by E. F. Biagini (Cambridge: Cambridge University Press, 1996), 120-47. Leading Free Churchmen like Robert Rainy would awkwardly attempt to legitimise the reasons for their adoption of "Seceder New Licht" disestablishment opinion and merge this into Orthodox Presbyterianism. Rainy would say that the Free Church was not inclined "to abandon her old theoretical ground." However, "the Free Church" wishes "the removal of the present Scottish Establishment," since "it is based on wrong principles, and ... its existence is unreasonable and unjust." See R. Rainy, "Disestablishment in Scotland," Contemporary Review 41 (1882): 431-44.

51. S. J. Brown, "Religion and the Rise of Liberalism: The First Disestablishment Campaign in Scotland, 1829-1843," Journal of Ecclessiastical History 48 (1997): 682-704.

52. Annals and Statistics, edited by Scott, 38. M'Kerrow, Secession Church, 372-73. 
"New Licht" Seceders generally assumed an apparently critical stance towards the Reformation Fathers in such issues as religious and civil liberty. They further propounded the revision of the Westminster Confession of Faith in accordance with the requirements of a changing world. For example, George Lawson, one of the leading figures of "New Licht" Movement, presented this approach in his short pamphlet Considerations on the Overture, which essentially handled the issues of civil magistrate and toleration. ${ }^{53}$ For Lawson, some principles of the Westminster Confession of Faith could be changed or revised. Even the Reformation Fathers, who had formulated the Westminster Confession of Faith, did not "claim for them the honour of infallibility." ${ }^{4}$ Lawson argued against "a blind deference" to every deed and opinion of the Reformation Fathers. It was "slavish meanness to follow their judgement" without regarding whether it was well- founded..$^{55}$ Lawson wrote that the reformers, as "our venerable ancestors, had not clear views of the natural rights of man," because the "notions of toleration" that were "so common" in the enlightened age of civil and religious liberty had been "rare" in the Reformation period. ${ }^{56}$

It should be indicated that the individualistic interpretation of religion, the questioning of the Westminster Standards, and the voluntarist ecclesiology inherent in the "New Licht" movement not only affected the stance of the Burghers, but also transformed the attitudes of the majority of the AntiBurghers. "The emergence" of the "New Licht" movement would divide "the Burghers and Anti-Burghers into four separate denominations between 1799 and 1806." ${ }^{57}$ Like the division among the Burghers in the Associate Synod in 1799, Thomas M'Crie and his friends, as a minority of the "Auld Licht Anti-Burghers," separated from the Anti-Burgher Synod and in 1806 formed the Constitutional Associate Presbytery. This was in reaction to the increasing influence of the "New Licht" attitudes among their Anti-Burgher brethren. ${ }^{58}$ As the biographer of M'Crie attested, "the events and opinions which

53. For Lawson's views on the duty of civil magistrate see J. MacFarlane, The Life and Times of George Lawson with Glimpses of Scottish Character From 1720 to 1820 (London: Hamilton \& Co, 1862), 356-60; and M'Kerrow, Secession Church, 587-90.

54. G. Lawson, Considerations on the Overture, Lying Before the Associate Synod, Respecting Some Alterations in the Formula Concerning the Power the Civil Magistrate in Matters of Religion; and the Obligation of our Covenants, National and Solemn League on Posterity (Edinburgh, 1797), 24.

55. Lawson, Considerations on the Overture, 24 and 28.

56. Lawson, Considerations on the Overture, 41-42.

57. Brown, Religion and Society, 24. For a discussion of the variety of reasons leading to the dissemination of voluntarist ideas among the Scottish Dissenters along with radical/progressive politics, see Brown, "Religion and the Rise of Liberalism," 682-704. For a brief summary of cultural and socio-economic reasons for the growth of "New Licht" theology, see Brown, Religion and Society, 24.

58. M'Kerrow, Secession Church, 446-53; and M'Crie the Younger, Life, especially 95-114. "New Licht Anti-Burghers" would unite with their Burgher counterparts as the United Secession Church in 1820. For this process, see M'Kerrow, Secession Church, 666-70; M'Crie the Younger, Life, 44. As a response to the formation of the United Secession Church, M'Crie published Two Discourses On The Unity Of The Church, Her Divisions, and Their Removal (Edinburgh, 1821). According to his biographer, the main intention of M'Crie was "to point the fallacious and unscriptural character of modern plans of union, particularly, that adopted by the United Secession." See M'Crie The Younger, Life, 260. M'Crie and his brethren united with those "dissatisfied with the union of the Burgher and Anti-Burgher Synods in 1820" and formed the Associate Synod of Original Seceders in 1827. See M'Crie the Younger, Life, 299. 
accompanied the political agitations of the close of the last century, and the beginning of the present," were influential "on the minds of Seceders." 59

Thomas M'Crie's historical works were largely a part of this "Auld Licht" - "New Licht" controversy. Yet, it is necessary to avoid giving a onedimensional depiction of M'Crie's attitude to this debate. In the 1790s the young M'Crie had embraced the "New Licht" ideas concerning the power of the magistrate in religious issues. ${ }^{60} \mathrm{M}$ 'Crie and his friends refused to be ordained in 1796. He demanded the Anti-Burgher Synod to revise the Covenanting Subscription Formula "by passing an act, declaring that they disapproved 'everything in the Confession of Faith, which, taken by itself, seems to allow the punishment of good and peaceful subjects, on account of their religious opinions and observances'." ${ }^{61}$ Later on, M'Crie would ironically abandon his "New Licht" inclinations for an "Auld Licht" position, mainly because of the fact that he was attached to the Establishment principle. He would directly attack "New Licht" ideas. ${ }^{62}$

It was thus mainly M'Crie's identity as an "Auld Licht Anti-Burgher" minister and spokesman in the debate about the religious profession that moved him to start writing his historical works. M'Crie observed to one of his friends that "had it not been for 'new-light', he would probably never have thought of writing" his Life of John Knox. ${ }^{63}$ For the "Auld Licht Anti-Burghers," the old principles such as the role of magistrates in maintaining as well as professing the true religion and the adherence to the Covenants of the seventeenth century were essential and seriously threatened by "New Light." ${ }^{64}$ This meant a condemnation of the Reformation Fathers, from whose stance the position of the Covenanters was thought to be derived. Furthermore, excessive zeal in indicating loyalty to George III, although occasioned by hostility to Revolutionary France, led to the articulation of principles tolerant of English episcopacy and Erastianism. In his Life of John Knox M'Crie maintained this view:

The alarm produced by that revolution which of late has shaken the thrones of so many of the princes of Europe, has greatly increased this party; and with the view of preserving the present constitution of Britain, principles have been widely disseminated, which, if they had been generally received in the sixteenth century, would have perpetuated the reign of Popery and arbitrary power in Scotland. ${ }^{65}$

\footnotetext{
59. M'Crie the Younger, Life, 44.

60. M'Kerrow, Secession Church, 382.

61. M'Kerrow, Secession Church, 437.

62. M'Crie the Younger concedes his father's "New Licht" stance in his young age and says apologetically that "his leanings were originally in favour of the new doctrines, and that the result of all his previous reading and reflection, which was tantamount to that of most young men at his age, went to confirm these early prepossessions." He further compares his father's change of position to the significant transformations in the lives of people like Saul of Tarsus, Luther, Knox, and Henderson by indicating that "in similar circumstances" they "have found the erroneous convictions of early life overruled for establishing their own minds in the truth, and qualifying them for more effectively maintaining the cause which they were left for a time to be misapprehend." M'Crie The Younger, Life, 63.

63. M'Crie the Younger, Life, 162.

64. D. Rupp, He Pasa Ekklesia: An Original History of the Religious Denominations at Present Existing in the United States (Harrisburg, 1844), 23-24.

65. M'Crie, Knox, 355.
} 
M'Crie, of course, held the view that the church constituted a sovereign kingdom, in no way dependent on the civil state. The Life of Andrew Melville served to remind readers of the doctrine of the Two Kingdoms. Inevitably, the famous speech of Melville to James VI was quoted, calling for the obedience of the civil state to Christ's Kirk:

I must tell you, there are two kings and two kingdoms in Scotland: there is King James, the head of this commonwealth, and there is Christ Jesus, the King of the Church, whose subject James the Sixth is, and of whose kingdom he is not a king, nor a lord, nor a head, but a member. Sir, those whom Christ has called and commanded to watch over his church, have power and authority from him to govern his spiritual kingdom both jointly and severally; the which no Christian king or prince should control and discharge, but fortify and assist; otherwise they are not faithful subjects of Christ and members of his church. ${ }^{66}$

The Scots came to regard the ideas of Knox and Melville as a guide to be followed in the main political and religious conflicts of this period, and M'Crie attempted to revive their legacy with a zealous Presbyterian historiography. However, although M'Crie's purpose was to remind his readers of past events, to restore the past by means of document-based historical writing, and to respond to Enlightenment writing with a Counter-Enlightenment discourse, his histories also displayed the basic tenets and features of Scottish Enlightenment historiography. This is observed in his discussion of the concept of civil liberty, which was commonly used for the dissemination of Enlightenment notions.

\section{The Concept of Civil Liberty in the Service of Counter-Enlightenment}

No other body of writing from Thomas M'Crie's pen so impressively demonstrates his utilisation of the Scottish Enlightenment debate for Restorationist and Counter-Enlightenment purposes as his historical works, particularly with regard to the issue of civil liberty. These works offer a lucid illustration of the Enlightenment-influenced aspects of M'Crie's intellectual identity. Whatever their purpose, his arguments were frequently aided by the rhetoric of Enlightenment, and visible in them was a convergence of Enlightenment and CounterEnlightenment notions. It is well known that the profound interest taken by the Scottish Enlightenment figures in the evolution of mankind and society, which they traced through categorically determined stages from savagery and rudeness to modern social structures, was instrumental in allowing for a palpable analysis of social change that relied on the term "progress." ${ }^{67}$ For instance, Adam Ferguson explicitly argued that the progress of "the species itself from rudeness to civilization" was reflected in the individual improvement "from infancy to manhood." William Robertson likewise considered the history of

66. M'Crie, Melville, 181.

67. A. Swingewood, "Origins of Sociology: The Case of the Scottish Enlightenment," British Journal of Sociology 21 (1970): 164-80; and H. M. Hopfl, "From Savage to Scotsman: Conjectural History in the Scottish Enlightenment," Journal of British Studies 17 (1978): 19-40. 
man as "his progress through the different stages of society, as he gradually advances from the infant state of civil life towards its maturity and decline." ${ }^{\circ 8}$

Even though M'Crie criticized the Enlightenment writers' understanding of the Scottish Reformation, he employed a similar progress-based, temporally comparative, approach as he discussed the emergence of the Reformation. Thus he pointed out that the political principles and doctrines of the Reformation period were shaped by "the spirit of the age, and were accommodated to a state of society and government comparatively rude and unsettled." ${ }^{69}$ M'Crie's progress-based reading reveals itself in his wider interpretation of history as a transforming force which becomes observable in comparing one historical era with another, and which confirms the existence of a positively evaluated progress. As M'Crie constructed his account with an emphasis on traditional Presbyterianism, he employed the stadialist approach, indicating the backwardness of earlier times and the progressive importance of the Reformation as "a signal triumph of truth over error." ${ }^{\text {70 }}$ Furthermore, his employment of a progressive and stadialist approach is clearly reflected in his discussion of civil liberty.

When looked at from the stadialist perspective of the Scottish Enlightenment historiography, the orthodox Presbyterian tradition seemed to be a disruptive force inimical to civil society and civil liberty, and thus a hindrance before progressive development. The Enlightenment historians asserted that what they called as the "progress of civil liberty" was fully consistent with the more general improvements in the history of civilisation. ${ }^{71}$ Thus, in an optimistic fashion, they were able to read and interpret the history of mankind as a history of liberty. In this process, it was necessary for a ruler to stand at an equal distance from all religious sects for the sake of "every consideration of public liberty, science, reason, industry and even his own independency." 72 In this context, the orthodox Presbyterian tradition was sharply criticised and the criticisms did not solely belong to secular writers such as David Hume.

The Moderate Party in the Church of Scotland willingly adopted such beliefs while seeking models for a theoretical and philosophical analysis of history. Thus, with a flexible understanding of the relations between church and state (they envisioned a reformed Kirk that cooperated on equal terms with the existing political regime) as well as between church and community, they opposed the Popular Party (another name for the Evangelicals within the Church of Scotland) and other dissenters, and rejected the Popular attachment to Scotland's theocratic past. ${ }^{73}$ Considering William Robertson's leadership of the Moderate party in the Established Church, his discussion of the Scottish

68. A. Ferguson, An Essay on the History of Civil Society, 2nd ed. (London, 1768), 2; and W. Robertson, The History of America, 3rd ed., 2 vols. (London, 1780), ii. 50.

69. M'Crie, Knox, 189.

70. M'Crie, Knox, 24.

71. C. Kidd, "Eighteenth Century Scotland and the Three Unions," in Anglo-Scottish Relations from 1603 to 1900 , edited by T. C. Smout (Oxford: Oxford University Press/British Academy, 2005), 171-87.

72. David Hume, Dialogues Concerning Natural Religion (London, 1779), 252.

73. I. D. L. Clark, "From Protest to Reaction: The Moderate Regime in the Church of Scotland, 1752-1805," in Scotland in the Age of Improvement, edited by N. T. Phillipson and R. Mitchison (Edinburgh: Edinburgh University Press, 1996), 200-224. 
Reformation era in terms of civil liberty and progress must be seen as a very deliberate enterprise. Although Robertson remained "convinced of the eternally valid core of Kirk doctrine" 74 and accepted the significant and valuable contribution of the Scottish Reformation era to the development of liberty in Scotland, he did not consider the issue as an ecclesiological one. It was not the peculiar doctrinal identity of Scottish Calvinism that was to be praised. Robertson saw the theocratic beliefs of seventeenth-century Presbyterians as a factor that produced "ignorance and obscurity" in the Scottish nation, in complete contrast to nations such as England that were engaged "in the pursuit of fame and knowledge." 75

In his interpretation, the Scottish Reformation was indeed a historical stage in the progress of civil liberty, but the most significant contribution to civil liberty and progress came with the Union of Scotland with England in 1707. This made Scotland and England into one nation and placed his contemporary Scots in a privileged position as they came to possess more developed liberties than their ancestors. ${ }^{76}$ This view clearly served the Moderate desire "to modify the Calvinist Kirk rather than to replace it," 77 accepting the positive aspects of the Reformation while rejecting the disruptive character of the theocratic Covenanting ideology. M'Crie was the pupil of Archibald Bruce (1746-1816), Professor of Divinity at the Anti-Burgher General Associate Synod. Like his mentor and others, M'Crie identified and underlined that the significance of the Scottish Reformation tradition lay in its distinctiveness from the English Reformation in the issue of civil liberty. This revealed a stance that was regarded as a threat for the British state by some in authority who equated the political principles of the Seceders with those of the Jacobins. ${ }^{78}$ Bruce pointed out that "civil and religious liberty" were "but two great branches of the same expanded tree. They have been found most intimately allied." 79 Further, he thought that "the Scots nation was before the union as free and independent, in every

74. Kidd, Subverting Scotland, 192 .

75. W. Robertson, The History of Scotland During The Reigns of Queen Mary and Of King James VI Till His Accession To The Crown Of England. With A Review Of The Scottish History Previous To That Period: And An Appendix, Containing Original Letters (New York, 1836), 322. For a discussion of William Robertson's thoughts on the issues of civil liberty and Scottish Reformation past, see Kidd, Subverting Scotland, 185-204.

76. Robertson, History of Scotland, 322.

77. J. G. A. Pocock, Barbarism and Religion: Narratives of Civil Government, Vol. II (Cambridge: Cambridge University Press, 1999), 302. Pocock discusses both Hume's and Robertson's historical conceptions in a very detailed way in the second part of the book.

78. J. Brims, "The Covenanting Tradition and Scottish Radicalism in the 1790s," in Covenant, Charter and Party: Traditions of Revolt and Protest in Modern Scottish History, edited by T. Brotherstone (Aberdeen: Aberdeen University Press, 1989), 50-62; Kidd, Subverting Scotland, 201. G. Pentland, "The French Revolution, Scottish Radicalism and the People "Who Were Called Jacobins,", in Reactions to Revolutions: The 1790s and its Aftermath, edited by U. Broich, H. T. Dickinson, E. Hellmuth and M. Schmidt (Berlin: Lit Verlag, 2007), 85-108. In the words of Henry Cockburn, a contemporary early-nineteenth-century figure, "Everything rung, and was connected with the Revolution in France." H. Cockburn, Memorials of His Time (Edinburgh, 1856), 82.

79. A. Bruce, Reflections on Freedom of Writing; and the Impropriety of Attempting to Suppress it by Penal Laws (Edinburgh, 1794), iii. Bruce's views on civil liberty and church-state relations were quite similar to M'Crie and dependent on a criticism of Enlightened Presbyterianism. See Kidd, Subverting Scotland, 200-201; and Kidd, "The Kirk, the French Revolution," 213-34. 
respect, as England: and the English part of the legislature can claim no kind of authority over it but in virtue of that treaty alone." 80

Like Bruce, M'Crie thought of civil liberty fundamentally as an ecclesiological problem, which might be explained clearly with reference to the debate over the extent of the authority of the civil magistrate and the extent to which church and state were separated. For him, the Second Book of Discipline had formulated the framework "by laying down the essential line of distinction between civil and ecclesiastical power." For this reason, they were "to co-operate within their respective spheres and fortify each other." ${ }^{81}$ Yet, M'Crie regarded the Scottish Reformation past as the foundation of civil liberties. The rejection of this fact and the acceptance of the relative superiority of the English religio-political system over the pre-Union Scottish theocracy, and finally the appreciation of the English case as a progress of civil liberties, were simply an attack on the basic tenets of Presbyterian-Calvinism as well as a tacit approval of English Erastianism. He drew attention to this point often enough. It was M'Crie's self-appointed task to trace the divergence of the religious cultures of Scotland and England back to the Reformation. He claimed that the origins of what he thought as the deviation of the English from "the path of true religion" lay in the political circumstances of the period. It was true that Henry VIII had commendably "renounced subjection to the Roman See and compelled his subjects to follow his example," but it had been a suspiciously self-interested enterprise. Moreover, the fact that this was a reformation imposed from above changed the character of the English Reformation for much the worse: Henry "invested himself with the ecclesiastical supremacy within his own dominions, which he had wrested from the Bishop of Rome." ${ }^{82}$ Thus, although Henry had broken off with Rome, he could not renounce his Catholicism:

Statutes against the authority of the pope, and against the tenets of Luther, were enacted in the same parliament; and Papists and Protestants were alternately brought to the same stake. The Protestants in Scotland were universally dissatisfied with this bastard reformation, a circumstance which had contributed not a little to cooling their zeal for the lately proposed alliance with England. ${ }^{83}$

As a result, the Reformation "was conducted on very different principles in England and Scotland, both as to worship and ecclesiastical polity." While "in England the papal supremacy was transferred to the prince, the hierarchy being subjected to the civil power," and "the principle forms of the ancient worship were retained," in Scotland "all of these were discarded as destitute of divine authority, unprofitable and burdensome." The "worship and government of the Church" had been "reduced to the primitive standard of scriptural simplicity." 84 Although there were problems related to the organization of the Reformed

80. Archibald Bruce, Free Thoughts On The Toleration of Popery, Deduced From A Review of its Principles and History, With Respect To Liberty and The Interests of Princes and Nations (Edinburgh, 1780), 359.

81. M'Crie, Melville, 56.

82. M'Crie, Knox, 27.

83. M'Crie, Knox, 28.

84. M'Crie, Knox, 62. 
Kirk, the Reformed religion had been generally accepted in Scotland. M'Crie went on to observe that there had been attempts since the Reformation to introduce foreign laws in matters like ecclesiastical government, and in particular to establish episcopacy. This was inevitably a danger to "the public tranquility." The Anglican Church was an alien and threatening power, as much as the Catholic Church. In the past, it had worked to smooth the way for the introduction of episcopacy in Scotland ${ }^{85}$ In summary, M'Crie thought that there was no distinction between the civil and religious liberties in the previous centuries. Religious and civil authorities, in conjunction, had removed any possible threat of "ecclesiastical supremacy and Erastian encroachments on the church." 86

M'Crie's conceptualization of civil liberty in his historical works clearly reflects his use of history for his restorationist and dissenting position. Thus he stressed that "the dangers to which the reformed religion and the liberties of the nation were exposed during the early administration of" James VI, and the defeat of his policies after long and bitter struggles, were highly important affairs that would affect the future course of Scotland and Britain. ${ }^{87}$ But this conception of civil liberty especially reveals how M'Crie consciously restricted the issue of civil liberty to the confines of the religio-political controversies of Melville's age. Although there is no evidence of M'Crie's employment of the word "theocracy" or its derivatives in his Reformation biographies, his depiction of the true form of government reflected theocratic convictions in harmony with the general revival of theocratic ideas among the Evangelicals. Some extreme Scottish Evangelicals, who saw political order as only one issue among many other administrative matters, conventionally regarded the traditional Calvinist-Presbyterian ecclesiology and its theocratic system during the sixteenth and seventeenth centuries as a seminal component of religious principles. ${ }^{88}$ For this reason, the continuity of the nation's political and social institutions had to be valued, and the community had to take precedence over the individual. M'Crie put forward this idea very clearly in one of his polemical works:

When public and private claims interfere and clash, the latter must give way to the former; and when any lawful authority is proceeding lawfully within its line of duty, it must be understood as possessing a rightful power to remove out of the way everything which necessarily obstructs its progress. ${ }^{89}$

85. M'Crie, Melville, 68-69.

86. M'Crie, (Edinburgh, 1836), 334.

87. M'Crie, Melville, vii.

88. A. B. Erickson, "The Non-Intrusion Controversy in Scotland, 1832-1943," Church History 11 (1942): 302-25. There were actually different visions of the godly nation among the Scottish Evangelicals of the early nineteenth century. These visions were changing from willingness for the imposition of the coercive religious uniformity to the "Godly Commonwealth" ideal of Thomas Chalmers, which contains flexibly the acceptance of liberty of conscience. For the theological differences between the extreme and Moderate Evangelicals see B. Hilton, The Age of Atonement: The Influence of Evangelicalism on Social and Economic Thought, 1785-1865 (Oxford: Oxford University Press, 1992), 91-100 and 201-215. For Chalmers' thoughts see S. J. Brown, Thomas Chalmers and the Godly Commonwealth in Scotland (Oxford: Oxford University Press, 1992).

89. M'Crie, Two Discourses, 135. 
M'Crie's concentration on the concept of a true church, and on corporate social unity around this establishment with its theocratic regime, brought about an exposition of his traditional thinking. As indicated above, what M'Crie understood from church-state relations was a mutual relationship between them. The absolute authority of the church, particularly in ecclesiastical jurisdiction, was essential to preserve social stability and order. Any threat to the harmony of this order would actually be a threat to civil liberty. The essential task for M'Crie, as he wrote in one of his papers on the voluntary controversy, was to encourage a stand against "the principles and designs of some modern infidels and politicians, which tend to make a total separation of civil government and religion, as if the interests of the latter in no shape pertained to the former" a violent contradiction of central principles of the Reformation. ${ }^{90}$

It appears that M'Crie saw his own historical interpretation as an expression of given historical and perennial Protestant truths. He believed in contrast that the Enlightenment style of historiography, as a historical construction, was shaped by a process of transformation in Scottish political life that took place throughout the eighteenth century. M'Crie was indignant and surprised at the attitude of enlightened philosophical writers, which he expressed as an "abhorrence" of the principles avowed by Knox and Melville. ${ }^{91}$ Although M'Crie essentially criticises both William Robertson's and David Hume's accounts of civil liberty as well as their approach to the Scottish Reformation past, it is quite clear that he was actually provoked to defend the Scottish Reformation Fathers far more by Hume's History of England than by Robertson's History of Scotland. M'Crie makes a certain distinction between Robertson's and Hume's historical interpretations, and indicates this point very explicitly in his Life of John Knox:

The political prejudices and sceptical opinions of Mr Hume are well known and appear prominently in every part of his History of England. Regarding the various systems of religious belief and worship as distinguished from one another merely by different shades of falsehood and superstition, he has been led, by a strange but not inexplicable bias, uniformly to shew the most marked partiality to the grosser and more corrupt; has spoken with greater contempt of the Protestants than of the Roman Catholics, and treated the Scottish with greater severity than the English Reformers. ${ }^{92}$

For M'Crie, this is evident in Hume's account on the controversies between Queen Mary of Scotland and the Scottish reformers. Hume was actually convinced by "the crimes laid to her charge." But he deliberately disguised the

90. Thomas M'Crie, Statement of the Difference (Edinburgh, 1807), 234. Cited from M'Crie the Younger, Life, 88 .

91. M'Crie, Knox, 188.

92. M'Crie, Knox, 355-56. It is possible to detect in M'Crie's writings similar thoughts about Hume's interpretation of the role of the Puritans during the English Civil War. Against Hume's unfavourable representations of the Covenanters as the men with "full of barbarism and ignorance," M'Crie tried to highlight the Covenanters' "enlightened zeal for civil liberty." M'Crie also reckons that another historian of the period, Malcolm Laing, borrowed most of his ideas on the Puritans from Hume's work. M'Crie, Vindication of the Covenanters, 103-06. For a discussion of Hume's view of the Puritans, see particularly J. Seed, Dissenting Histories: Religious Division and Politics of Memory in Eighteenth-Century England (Edinburgh: Edinburgh University Press, 2008), 73-98. 
"unvarnished statement of facts and fixed "the attention of his readers on an untrue and exaggerated representation of rudeness of Knox and other reformers." 93 However, Robertson was not "actuated by such improper motives." What was wrong and surprising with his account in his History of Scotland was that Robertson gave a more favourable description of Queen Mary "than all the defences of her most zealous and ingenious advocates." This was a consequence of the prejudices and false assumptions instigated in public mind about John Knox and his friends, who were "entitled to the gratitude and veneration of posterity." 95

According to M'Crie, the enlightened rejection of the belief that the Scottish Reformation had established true civil liberty originated from or was closely associated with a dislike of Knox and Presbyterianism. Having issued from the supporters of the British monarchy of the sixteenth century, it was adopted by others after the Revolution of 1688 . M'Crie identified their ideas as originally stemming from Catholicism. ${ }^{96}$ Nevertheless, M'Crie's identification of Catholicism with the views of Enlightenment thinkers seems quite problematic. Actually, both Hume and Robertson employed a conspicuous antiCatholic discourse in their works. As a reflection of their Enlightenment point of view as well as of the traditional Protestant anti-Catholicism prevailing in Scotland, they regarded Catholicism as a major obstacle before progressive society and rationalism. Robertson considered Popery as "a species of false religion" which, "improved by the experience and observation of many successive ages, ... arrived at last to a degree of perfection which no former system of superstition had ever attained." ${ }^{\text {97 }}$ Likewise, Hume — who had a generally anti-religious stance — insisted that "Modern Judaism and Popery, (especially the latter) being the most unphilosophical and absurd superstitions which have yet been known in the world, are the most enslaved by the priests." 98 Consistent with this rationalistic and progressive Enlightenment language, M'Crie welcomed the Reformation for the "overthrow of superstition, ignorance and despotism," 99 which were for him inherent features of Catholicism. In this sense, what is striking is that although the anti-Catholic discourse of Enlightenment thinkers is evident and very similar to that of M'Crie's, he deliberately ignored these facts and posited a direct relationship between their views and Catholicism. Thus anti-Erastian and anti-Episcopalian argumentations combine with anti-Enlightenment and anti-Catholic ones in M'Crie's Calvinist-Presbyterian historiography, with the differences between them melting into the air.

For M'Crie, the ideas of the Enlightenment writers had been produced "by the friends of absolute monarchy" in Knox's time. Following the Revolution of

93. M'Crie, Knox, 356.

94. M'Crie, Knox, 356.

95. M'Crie, Knox, 357.

96. M'Crie, Knox, 354-55.

97. Robertson, History of Scotland, 141

98. D. Hume, Essays, Moral and Political (Edinburgh, 1826), 84.

99. M'Crie, Knox, 16. 
1688 , they were adopted "by the adherents of the Stuart family, whose religious notions, approximating very nearly to the Popish," combined "with their slavish principle respecting non-resistance to kings," and led them to reject "almost every measure adopted at the time of the Reformation, and to condemn the whole as a series of disorder, sedition, and rebellion against lawful authority." These views did not disappear with the overthrow of the Stuart family. Rather, "the spirit by which the Jacobitish faction was actuated" was maintained when the supporters of Stuart family "transferred their allegiance to the house of Hanover." Such views were now disseminated very zealously in the period following the French Revolution, and threatened civil liberty under the guise of "preserving the present constitution of Britain." Enlightenment writers were deeply affected according to M'Crie by the Jacobite idea of non-resistance, and took it over by submitting to the Erastian control of the uncovenanted Hanoverian king. ${ }^{101}$ Those writers were also under the influence of "the increase of infidelity and indifference to religion in modern times," and suffered the consequent intellectual inadequacy. They had been fascinated with the illusion that the world could be emancipated "from superstition and priestcraft." It was very difficult for such men to understand the value of the Reformation heritage, since they were "naturally" inclined to "despise and dislike men who were inspired with the love of religion.". 102

For M'Crie, it was impossible to make a distinction between ecclesiastical and civil liberty, since it was the principles of the Reformation that determined the content of that liberty. People began to perceive the notion of civil liberty in its extended sense through the Presbyterian ideals of the Scottish Reformation. The acquisition of liberty was not an individual or factional issue, but had a communal significance, directly related to the salvation and freedom of a society. The Scottish nation came to understand that religious and civil liberties could be achieved through the struggle against the despotism and oppression of the rulers. ${ }^{103}$ Corresponding to his understanding of liberty, M'Crie believed in the identification of civil and ecclesiastical tyranny. It was possible for people to enjoy religious freedom only if they succeeded in emancipating themselves from civil tyranny. In short, the Scottish nation was "indebted" to the Protestant truth proclaimed during the sixteenth and seventeenth centuries "for the propagation of the genuine principles of rational liberty." 104 Then, the most important task for M'Crie was to demonstrate and prove the libertarian nature of the Scottish Reformation, awakening the human mind from the sluggishness and

100. M'Crie, Knox, 354-55.

101. For the main components and complexities of Jacobite political theology see especially P. K. Monod, Jacobitism and the English People, 1688-1788 (Cambridge: Cambridge University Press, 1989), ch. I; D. Szechi, The Jacobites, Britain and Europe 1688-1788 (Manchester: Manchester University Press, 1994), 26. For an illustration of how some Whigs employed the idea of nonresistance after the Glorious Revolution see J. C. D. Clark, English Society 1660-1832 Religion, Ideology and Politics During the Ancien Regime (Cambridge: Cambridge University Press, 2000), 111-12; H. T. Dickinson, Liberty and Property: Political Ideology in Eighteenth-Century Britain (London: Weidenfeld \& Nicolson, 1977), 75-78.

102. M'Crie, Knox, 357.

103. M'Crie, Knox, 183-84.

104. M'Crie, Knox, 185. 
the deep sleep of the Middle Ages. ${ }^{105}$ It was certainly not Presbyterianism that threatened to disrupt the civil society or undermine Scottish liberties. Knox, as a champion of civil liberties, had aided in constructing a language of political liberty by realizing the need and demand for a proper government to establish "justice and order." 106 He had "reminded" the Scottish nation "of the original equality of men." 107 His ideas were remarkably progressive in a very backward and rude society, with a correspondingly primitive government. ${ }^{108}$ Similarly, Andrew Melville had "an ardent attachment to civil liberty" and was not, as suggested by Enlightenment writers, a defender of an oppressive ecclesiastical system. ${ }^{109}$

The Enlightenment concept of civil liberty was essential for M'Crie in forging weapons for his Counter-Enlightenment and Restorationist attack. The Scottish Kirk had to be at the centre of the nation's civil society. This was what the Enlightenment writers failed to see in the Scottish past, and as a result they also failed to see civil liberty aright. The error that the Enlightenment thinkers committed in scorning the Scottish Reformation past and its founding fathers served the ends of the Erastian British state. This was, for M'Crie, treason against the legacy of the founding fathers of the Scottish Reformation. To a certain extent, M'Crie's Restorationist Counter-Enlightenment interpretation of the Reformation past was nurtured by a discomfort with Unionism and an opposition to various aspects of the existing political order. Although M'Crie was a devout Whig in political matters and held onto the Scottish Whig historiographical tradition, ${ }^{110}$ he was theologically conservative and his position on the question of civil liberty amounted to a radical rejection of the supposedly cosmopolitan Enlightenment Whig historiography on the Scottish Reformation: he criticised the Revolution Settlement of 1689 and the Union of 1707 as blows to the civil and religious liberties of the Scots. M'Crie's alternative focused on the Reformation as a true embodiment of civil liberty: he dismissed the eighteenth-century Unionist emphasis on the threat from France and the need to protect the Protestant British state against it, and stressed the threat posed by the dangerous ideas and influences that could mainly issue from the foreign Church of England and their allies in the Church of Scotland, but perhaps also from "infidels." M'Crie feared that the Scots of his own time sought to imitate the English both in worship and in ecclesiastical polity. Such an alarming change in the attitudes of the Scots was a clear indication of the influence of the English on them. ${ }^{111}$ Such an observation reveals that M'Crie's discussion of civil liberty was actually a profound complaint about the change in general attitude evident among many writers, particularly among those

105. M'Crie, Knox, 212-13.

106. M'Crie, Knox, 186-87.

107. M'Crie, Knox, 188-89.

108. M'Crie, Knox, 188-89.

109. M'Crie, Melville, 342.

110. For how M'Crie described himself as a true Whig, see M'Crie the Younger, Life, 473. For

M'Crie's Presbyterian Whiggism, also see M'Crie the Younger, Life, 417, 315-16.

111. M'Crie, Melville, 141-42; and M'Crie, Knox, 188. 
influenced by Enlightenment historiography, who propagated a much different and English-oriented definition of civil liberty.

\section{Conclusion}

M'Crie's Reformation biographies are significant in that they depict the particular contribution of a Seceder to contemporary intellectual debates in general and to the religio-political discussions in particular. His Scottish Reformation biographies reflected the intellectual taste and the historiographical orientations of his time. From a methodological point of view, they still represented the history-writing traditions of the early nineteenth century, without the sharp distinction between history and literature that was sought later. On the other hand, he drew upon the main characteristics of Enlightenment historiography, such as progressivism and historical teleology. However, M'Crie employed Enlightenment notions in a highly different fashion from his Enlightenment predecessors: he used them to construct an alternative to both Robertson and Hume, what we can call a powerful Counter-Enlightenment Presbyterian historical discourse. ${ }^{112}$

It should be pointed out in this context that M'Crie's discussion of civil liberty employs a heavily sectarian language. On the one hand, he attacked writers of the Scottish Enlightenment who he believed had adopted a large dose of Erastianism. On the other hand, he described their religio-political views as a remnant of Catholicism. Therefore, it is quite difficult to separate M'Crie's use of distinctively Enlightenment and anti-Catholic rhetoric from his antiEpiscopalian and well-established Calvinist-Presbyterian priorities. The views on the notion of civil liberty advanced in M'Crie's works represented a characteristic continuation of the eighteenth-century extreme "Whiggish critique of the Whig Revolution," 113 which regarded the Union as illegitimate and contrary to "the requirements of the 1643 Solemn League and Covenant." 114 This traditional Secession view survived after the Union, reproduced itself during the first half of the nineteenth century among the group of Seceders that included M'Crie himself, and assumed a sceptical attitude toward both the Revolution Settlement of 1689 and the Union of 1707. For the Seceders, showing disregard

112. Another interesting point, which can be mentioned briefly, is that as a CounterEnlightenment figure, M'Crie had a low esteem of nature. This was one of the typical characteristics of the Counter-Enlightenment position against Enlightenment optimism about the potential of human nature. As is well known, famous Counter-Enlightenment thinkers like Joseph de Maistre and Herder constantly emphasised the drawbacks and imperfection of human nature. In accordance with his attachment to traditional Orthodox Calvinist-Presbyterianism and his CounterEnlightenment view, M'Crie similarly thought that all human-beings had intrinsically "sinful infirmity." However, he paradoxically employed the Enlightenment concept of progress, which derived actually from its optimistic confidence in the potential of human nature. In this sense, M'Crie's use of the progress concept against Enlightenment historiography reveals the tension and dilemma evident in his Reformation biographies. However, this point can be a subject of separate research. See T. M'Crie, Sermons, 173. For the Counter-Enlightenment criticism about human nature, see Garrard, Counter-Enlightenments, 109-121.

113. C. Kidd, "Conditional Britons: The Scots Covenanting Tradition and the Eighteenth-century British State," English Historical Review 117 (2002): 1147-76.

114. K. Bowie, "Popular Resistance, Religion and the Union of 1707," in, Scotland and the Union 1707-2007, edited by T. M. Devine (Edinburgh, 2008), 39-53. 
for the Reformation and the Covenanting tradition was fundamentally unacceptable, as it amounted to the establishment of Erastianism and the usurpation of the civil liberty in Scotland. Thus the stress on civil liberty in M'Crie's historiography could be meaningfully read as a continuation or re-presentation of the eighteenth-century radical Presbyterian attitudes to the Union in the context of early nineteenth-century debate, which focused on the Erastianism. But, what distinguishes M'Crie's historiography regarding the question of civil liberty was his emphasis on the history of the Scottish Presbyterian tradition before the Revolution Settlement in order to contribute to the revitalisation of Calvinist-Presbyterian orthodoxy in the early nineteenth century.

M'Crie wrote in an age when an increasing number of people came to publish their opinions on a growing range of subjects, and the published literature found an increasingly wider audience. ${ }^{115}$ M'Crie addressed a sizeable mass of readers in such a convenient atmosphere. His Reformation biographies were widely known and read. ${ }^{116}$ In all these respects, M'Crie was much more a herald of nineteenth-century Scotland than the Enlightenment historians had been. After all, it was to be the century of Disruption and the Free Kirk, of Irish immigration and the creation of the Scottish sectarian tradition, ${ }^{117}$ which was nourished in part by views of the Scottish past that were derived more or less from those of M'Crie's. The reputation of M'Crie, which was second only to Scott's ${ }^{118}$ in his day, was due to the fact that his ideas were in tune with the rising tide of Evangelicalism, and remained so with the growth of sectarianism. That is why M'Crie's enthusiasm for the Scottish Reformation past constituted the most representative example of the Presbyterian interpretation, holding its own against the Enlightenment influence. M'Crie's history was no mere product of curiosity; it reveals a mindset to which historians should give more attention if they are to reach a more profound understanding of the conflicts of the period.

115. A. Murdoch and R. B. Sher, "Literary and Learned Culture," in People and Society in Scotland, I: 1760-1830, edited by M. Devine and R. Mitchison (Edinburgh: John Donald, 1988), 127-43.

116. P. R. Murray, "Religion," in The Edinburgh History of the Book in Scotland, III, Ambition and Industry 1800-1880, edited by B. Bell (Edinburgh: Edinburgh University Press, 2007), 287-95.

117. Leading figures of the Free Church like James Wylie and James Begg, who were among the founders of the Scottish Reformation Society in 1850, actively campaigned against Catholicism and employed heavily anti-Catholic discourse and sectarian idiom in their works. On the other hand, Free Church historiography was essentially a continuation and repetition of the main elements in M'Crie's historical works. It heavily drew upon the essential aspects of M'Crie's historiography such as strict attachment to Presbyterian past, the identification of Scottish national identity with Presbyterianism, and virulent anti-Catholicism. For these cases, see Forsyth, "The Presbyterian Interpretation of Scottish History," 143, 279.

118. Using the well-developed discourse of the Seceders, M'Crie displayed a strict attachment to the Covenanting tradition that existed as undercurrent throughout the eighteenth and early nineteenth centuries. In exactly the same way as his Reformation biographies, M'Crie constructed interconnections between the Covenanters and the Scottish religious and civil liberties as he criticised the representations of the Covenanters in Walter Scott's Old Mortality. Nevertheless, that debate remainst outside the subject of this article. See M'Crie, A Vindication. For a discussion of conflict between Scott and M'Crie on the Covenanters, see in particular D. M. Murray, "Martyrs or Madmen? The Covenanters, Sir Walter Scott and Dr Thomas McCrie," Innes Review 43 (1992): 166-75. 